\title{
Perforating granuloma annulare mimicking papulonecrotic tuberculid
}

\section{Granuloma anular perfurante simulando tubercúlide pápulo-necrótica}

\author{
Amanda Regio Pereira ${ }^{1}$ \\ Marina Pinhas Ariza Monteiro ${ }^{1}$ \\ Nilceo Schwery Michalany ${ }^{3}$ \\ Karime Marques Hassun ${ }^{5}$
}

\author{
Mariana Bellini Vieira ${ }^{1}$ \\ Milvia Maria Simões e Silva Enokihara² \\ Ediléia Bagatin ${ }^{4}$
}

DOI: http://dx.doi.org/10.1590/abd1806-4841.20132510

\begin{abstract}
A case is reported of a patient presenting lymph node tuberculosis and cutaneous lesions resembling papulonecrotic tuberculid, but histologically compatible with perforating granuloma annulare and which responded satisfactorily to antituberculous therapy. This is probably one of the first reports of the association of perforating granuloma annulare and tuberculosis, and it is important therefore to highlight the relevance of this disorder in the differential diagnosis of papulonecrotic tuberculid and to raise the hypothesis that this entity should also be considered to be a variant of tuberculid.
\end{abstract}

Keywords: Granuloma annulare; Hypersensitivity; Tuberculosis, cutaneous

Resumo: Os autores relatam o caso de uma paciente com tuberculose ganglionar e lesões cutâneas clinicamente sugestivas de tubercúlide pápulo-necrótica, porém com histopatologia compatível com granuloma anular perfurante, e que apresentaram melhora após tratamento para a tuberculose. Trata-se, possivelmente, de um dos primeiros relatos da associação de granuloma anular perfurante com tuberculose, salientando a importância desta entidade no diagnóstico diferencial da tubercúlide pápulo-necrótica e levantando a possibilidade da mesma ser considerada, também, uma variante de tubercúlide.

Palavras-chave: Granuloma anular; Hipersensibilidade; Tuberculose cutânea

\section{INTRODUCTION}

Granuloma annulare is a granulomatous inflammatory disease of unknown etiology which represents a peculiar reaction to a variety of triggering factors, such as insect bites, infections, neoplasias and other systemic conditions. ${ }^{1,2}$

Tuberculosis is one of the diseases possibly related to the aetiopathogenesis of granuloma annulare. However this association is not common. Few case reports exist that relate the occurrence of this skin condition simultaneously to lymph node tuberculosis, tuberculids and following tuberculin test. ${ }^{1,3,4}$
Tuberculids are distant hypersensitivity reactions to Mycobacterium tuberculosis. This denomination includes the group papulonecrotic tuberculid, lichen scrofulosorum and erythema induratum of Bazin. Patients react strongly to PPD and have a marked response to antituberculous therapy. ${ }^{5,6}$

Perforating granuloma annulare is a rare variant of granuloma annulare described in 1971 by Owens and Freeman. It is clinically manifested by umbilicated papule, that drain a serous fluid and become centrally covered by small plugs. There is a predilection for the extremities and a chronic course.

Received on 03.02.2013.

Approved by the Advisory Board and accepted for publication on 18.03.2013.

Work performed at the Universidade Federal de São Paulo (UNIFESP) - São Paulo (SP), Brazil.

Financial Support: None.

Conflict of Interests: None.

MD - Resident physician at the Department of Dermatology, Universidade Federal de São Paulo (UNIFESP) - São Paulo (SP), Brazil.

PhD awarded by São Paulo Federal University (UNIFESP) - Dermatopathologist at the Department of Dermatology and Pathology, Universidade Federal de São Paulo (UNIFESP) - São Paulo (SP), Brazil.

MS - Master's degree awarded by São Paulo Federal University (UNIFESP) - Dermatopathologist. Collaborating Professor at the Department of Pathology, Universidade Federal de São Paulo (UNIFESP) - São Paulo (SP), Brazil.

PhD awarded by São Paulo Federal University (UNIFESP) - Assistant Professor of the Department of Dermatology, Universidade Federal de São Paulo (UNIFESP) - São Paulo (SP), Brazil.

Master's degree awarded by São Paulo Federal University (UNIFESP) - Physician at the Department of Dermatology, Universidade Federal de São Paulo (UNIFESP) - São Paulo (SP), Brazil. 
Clinically, perforating granuloma annulare is quite similar to papulonecrotic tuberculid, which is a symmetric eruption of necrotizing papules that ulcerate and crust over, primarily affecting the extensor surfaces of the limbs. ${ }^{1,7,8}$

Although we found reports of the association of granuloma annulare and tuberculosis, the perforating variant has not yet been described as a cutaneous sign of mycobacterial infection.

\section{CASE REPORT}

A 19-year-old female patient was referred to the dermatologist because of lesions on the hands, elbows and knees of three-year duration. On examination, the patient presented erythematous papules, with a crusted umbilicated center, localized on the extensor surfaces of the limbs and dorsal aspect of the hands. She also had some pustules on the palmar surface of the fingers (Figures 1 and 2).

As comorbidity, she has had a diagnosis of systemic lupus erythematous ten years previously, conforming to the following criteria: discoid and malar rash, photosensitivity, coarse speckled nuclear antinuclear antibody and thrombocytopenia. She had previously been treated with oral corticosteroids, cyclosporine and methylprednisolone pulse therapy. Over the last six years, the disease was controlled and maintenance therapy was being performed with hydroxychloroquine.

Simultaneously to the skin changes, the patient had developed cervical adenomegaly, originating a 5centimeters diameter conglomerate. Fine-needle aspiration diagnosed a chronic granulomatous lymphadenitis with caseous necrosis. Ziehl-Neelsen stain and culture of mycobacteria resulted both negative in the aspirate. The patient showed a strong reaction to tuberculin $(28 \mathrm{~mm})$, leading to the formation of bullae, necrosis and a residual atrophic scar (Figure 3).

The initial diagnostic hypothesis was papulonecrotic tuberculid secondary to lymph node tuberculosis.

The patient was referred to the infectology clinic and was started on antituberculous polychemotherapy standardized in Brazil, consisting of rifampicin, isoniazid, pyrazinamide and ethambutol.

Histopathology of the skin revealed a palisading granuloma in communication with the epidermal surface and constituting an area of perforation. The granuloma was surrounded by a peripheral infiltrate of histiocytes and lymphocytes and had a central area of mucinous degeneration of collagen. The absence of necrosis and vascular involvement and the typical histological findings of perforating granuloma annulare undermined the initial clinical hypothesis that this was papulonecrotic tuberculid (Figures 4-6).

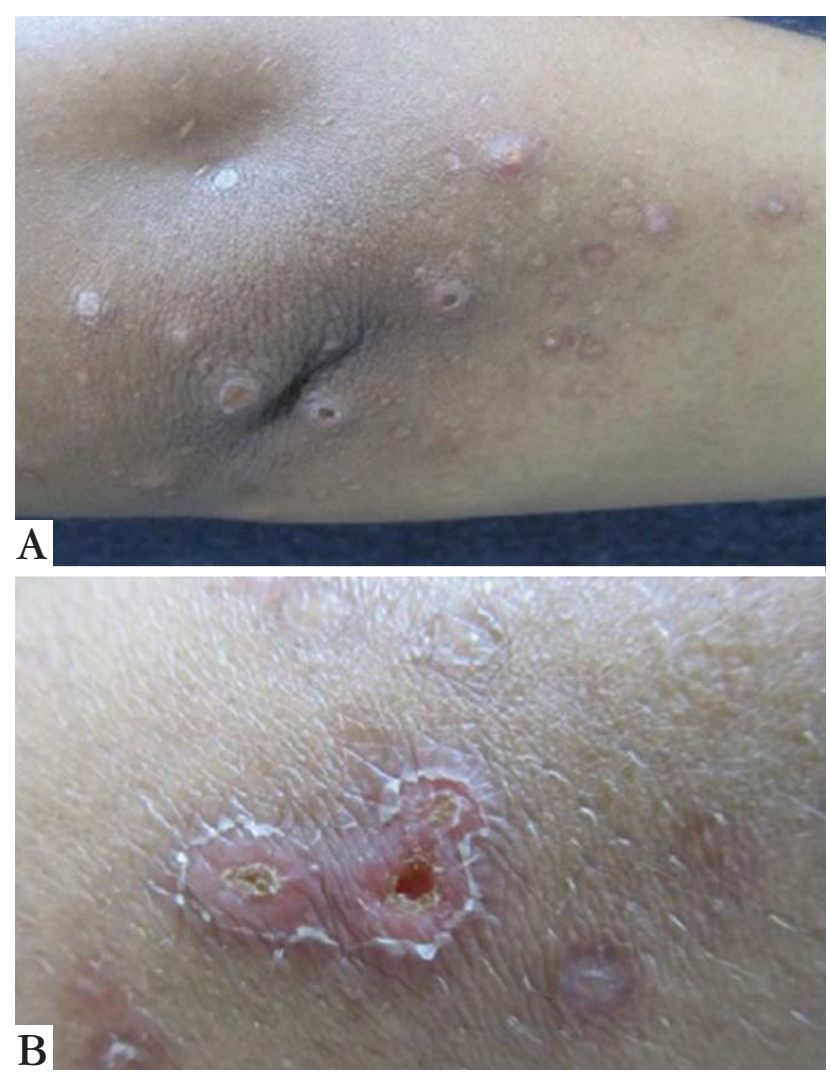

FIGURE 1: (A and B): Erythematous umbilicated papules centered by a small crust and with discrete perilesional desquamation, over the extensor surfaces of the upper limbs. Similar lesions were also found on knees and dorsal aspect of the hands

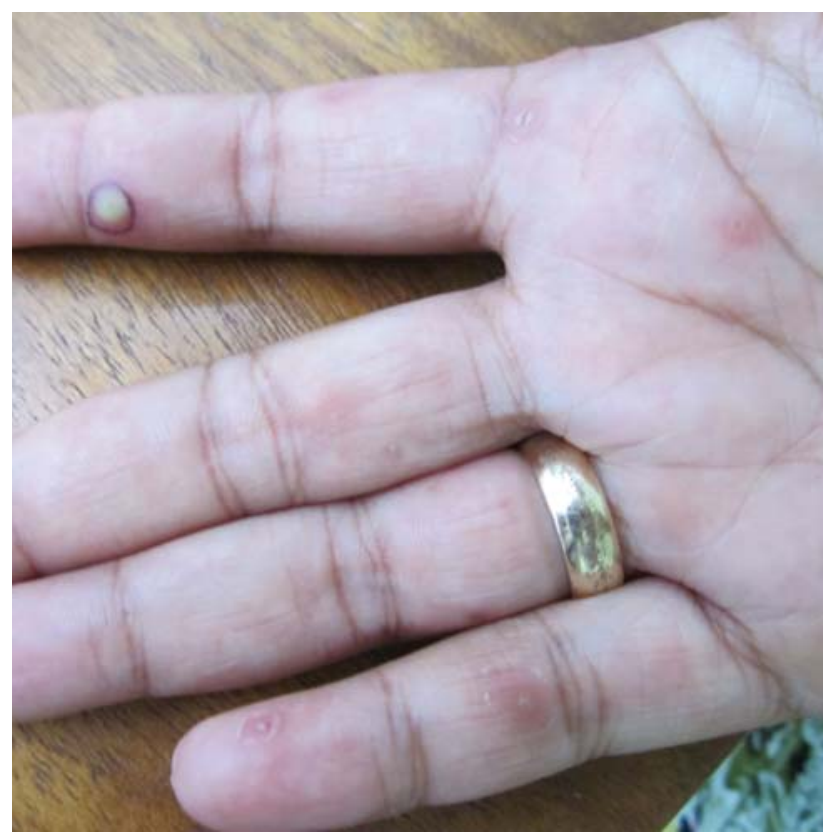

FIGURE 2: A pustule and erythematous papules in the palmar surface of the fingers and on the right palm 


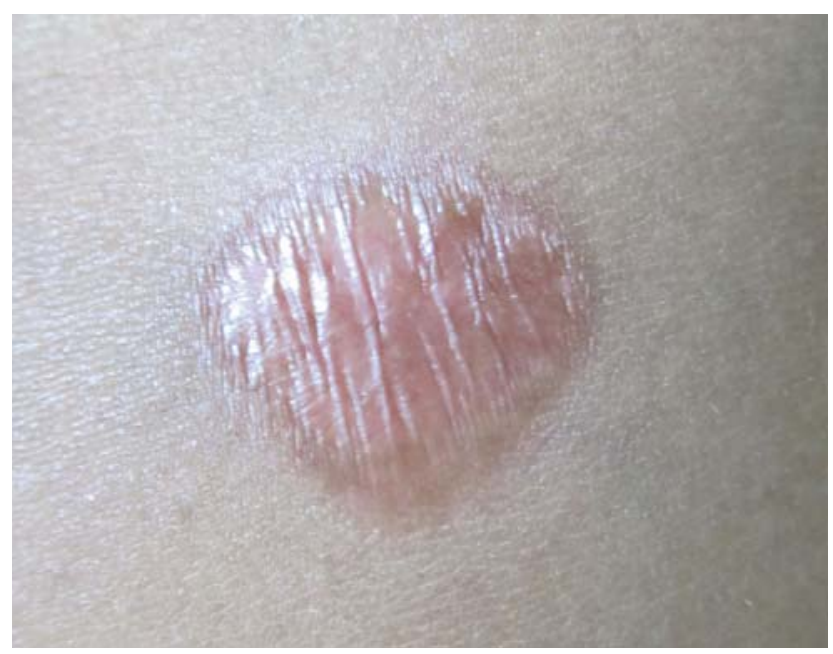

FIGURE 3: Residual atrophic scar resulting from strong reaction to tuberculin test on the right forearm

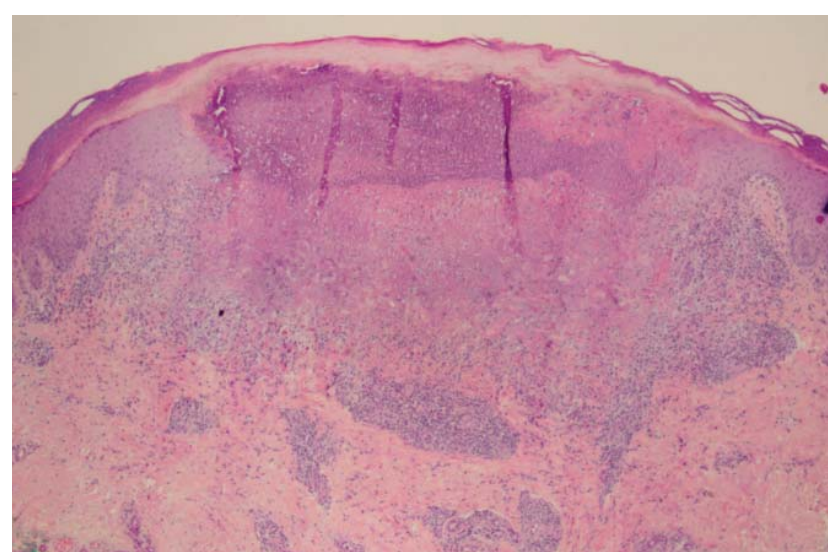

FIGURE 4: Skin fragment showing palisading granuloma communicating with surface in an area of perforation (Hematoxylin-eosin, 40x)

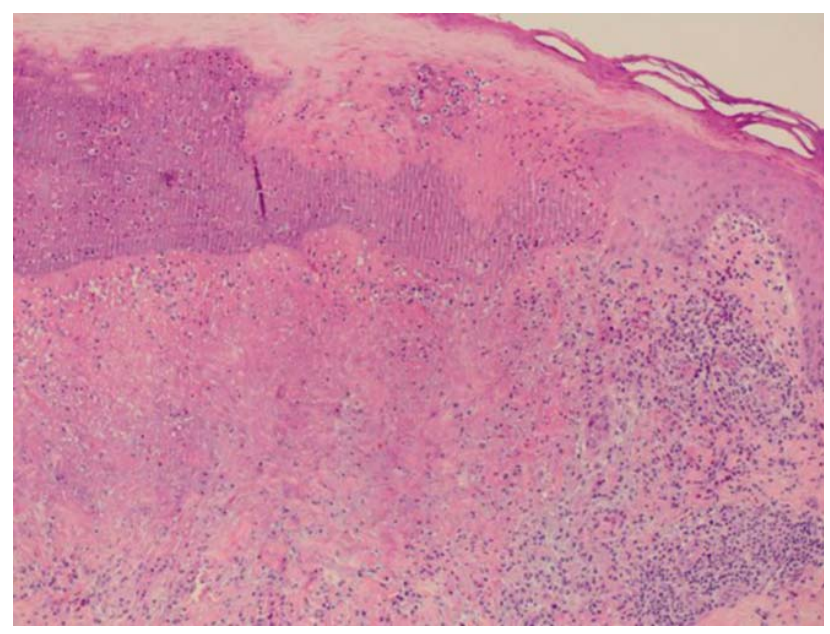

FIGURE 5: Perforating granuloma annulare with peripheral infiltrate of histiocytes and lymphocytes and mucinous degeneration of collagen in the center (Hematoxylin-eosin, 100x)

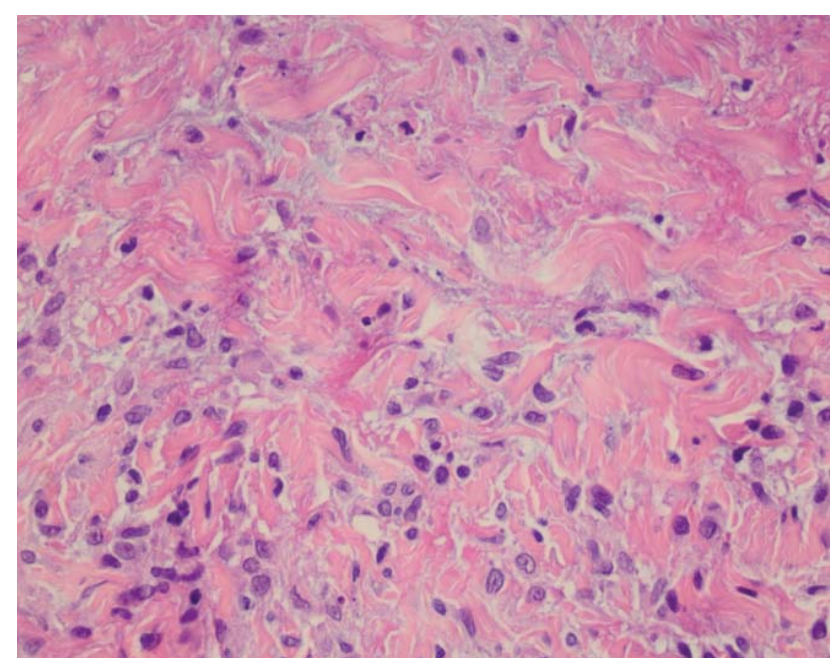

FIGURE 6: Close view of the granuloma central area, where it is possible to note the mucinous degeneration of collagen, stained in purple (Hematoxylin-eosin, 400x)

PCR-based detection of Mycobacterium tuberculosis resulted negative in a sample of a palmar pustule.

In the first weeks of antituberculous therapy, new papules or pustules stopped appearing. After six months, complete regression of the adenomegaly and cutaneous lesions was observed, including the palmar pustules.

Throughout the evolution of the disease and its treatment the patient showed no signs of lupus activity and remained on maintenance therapy with antimalarial.

\section{DISCUSSION}

In the reported case, the dermatologic scenario was clinically suggestive of papulonecrotic tuberculid. The histopathological study, however, did not reveal the expected morphology. The diagnosis of perforating granuloma annulare was thus considered more appropriate since it correlated clinical and histologically with the findings in this patient.

The description of the lesions on the extensor surfaces fitted that of perforating granuloma annulare. ${ }^{1,9}$ Pustules found on palms are not a typical finding, but have been previously reported in cases of perforating granuloma annulare, especially in the generalized form, when pustules can be found in up to $58 \%$ of patients. ${ }^{78,10}$

The negative results in the search for acid-alcohol resistant bacilli and PCR detection of M. tuberculosis in tissue samples do not exclude the hypothesis that the skin lesions were a manifestation of hypersensitivity to tuberculosis, given that in disorders of this type bacilli are not usually found, and molecular tests show a highly variable positivity. 
Specific staining to detect mucin could not unfortunately be performed given the scarce amount of tissue represented in the biopsy and the relatively fast response to treatment, which led to new lesions being rarely detected after a few weeks of treatment.

The good response to antituberculous polychemotherapy favored the conclusion that the cutaneous signs could be considered an immune reaction to the systemic infection.

A few reports in the consulted literature mention the association of granuloma annulare, especially the disseminated forms, with tuberculosis., ${ }^{3,4}$ After completing extensive research on the major online medical databases, we can probably assume that the perforating variant is reported here for the first time, as an "ide" reaction to $M$. tuberculosis.

The case presented raises the hypothesis that the granuloma annulare phenotype could be considered, sensum latum, to be also a type of tuberculid, since the definition of this term is hypersensitivity reaction to a distant focus of tuberculosis, a mecha- nism that has been demonstrated in the present case.

Perforating granuloma annulare should therefore be considered to be a major differential diagnosis in cases of cutaneous crusted papules emerging in a patient diagnosed with tuberculosis. It shares some clinical and histological similarities with papulonecrotic tuberculid, such as the morphology and distribution of the lesions, with an acral predilection, the hypersensitivity pattern to the underlying infection and the possibility of a palisading granulomatous infiltrate on histology. ${ }^{5}$ These similarities may lead to a misdiagnosis.

It is also important to rule out tuberculosis in cases of perforating granuloma annulare, especially in endemic areas.

\section{Acknowledgements}

The authors wish to thank Fleury - Medicina e Saúde for the courtesy of performing the molecular analysis of tissue samples in this case.

\section{REFERENCES}

1. Burns DA. Necrobiotic Disorders. In: Burns T, Breathnach S, Cox N, Griffiths C, editors. Rook's: Textbook of Dermatology. 8th. ed. Oxford: Blackwell Publishing; 2010. p. $60.1-60.12$

2. Sampaio SAP, Rivitti EA. Granulomas não-infecciosos. In: Dermatologia. 3. ed. São Paulo: Artes Médicas, 2007. p. 875-7.

3. Herron MD, Florell SR. Disseminated granuloma annulare accompanying mycobacterium tuberculosis lymphadenitis. Int J Dermatol. 2004;43:961-3.

4. Winkelmann RK. The granuloma annulare phenotype and tuberculosis. J Am Acad Dermatol. 2002;46:948-52.

5. Yates VM. Mycobacterial infections. In: Burns T, Breathnach S, Cox N, Griffiths C, editors. Rook's: Textbook of Dermatology. 8th. ed. Oxford: Blackwell Publishing; 2010. p. 31.21-31.30

6. Tsai J, Chen GS, Lan LH, Lan CC. Cutaneous tuberculid clinically resembling generalized granuloma annulare. Clin Exp Dermatol. 2007;32:450-1.

7. Dornelles SI, Poziomczyk CS, Boff A, Köche B, Dornelles Mde A, Richter GK. Generalized perforating granuloma annulare. An Bras Dermatol. 2011;86:327-31.

8. Penas PF, Jones-Caballero M, Fraga J, Sánchez-Pérez J, García-Díez A. Perforating granuloma annulare. Int J Dermatol. 1997;36:340-8.

9. Prendiville J. Granuloma Annulare. In: Wolff K, Goldsmith LA, Katz SI, Gilchrest BA, Paller AS, Leffell DJ, editors. Fitzpatrick's Dermatology in General Medicine. 7th. ed. New York: MacGraw-Hill; 2008. p. 369-73.

10. Gamo Villegas R, Sopena Barona J, Guerra Tapia A, Vergara Sanchez A, Rodríguez Peralto JL, Iglesias Dlez L. Pustular generalized perforating granuloma annulare. $\mathrm{Br}$ J Dermatol. 2003;149:866-8.

\author{
MAILING ADDRESS: \\ Amanda Regio Pereira \\ Rua Borges Lagoa, 508 - Vila Clementino \\ 04038-001 - São Paulo - SP \\ Brazil \\ E-mail: amandaregiopereira@gmail.com
}

How to cite this article: Pereira AR, Vieira MB, Monteiro MPA, Enokihara MMSS, Michalany NS, Bagatin E, Hassun KM. Perforating granuloma annulare mimicking papulonecrotic tuberculid. An Bras Dermatol. 2013;88(6 Suppl 1):S101-4. 